\title{
Eugene Garfield-Glimpses of his writings
}

\author{
B. K. Sen* \\ Department of History of Science, Indian National Science Academy, New Delhi, India
}

\begin{abstract}
Garfield in his active life used to contribute one article every week which appeared in Current Contents and some renowned journals. The articles thus contributed total around 1500. All these articles had finally appeared in the book called Essays of an Information Scientist in 15 volumes. The present article is based on the first five volumes of his Essays wherein the articles by Garfield have been initially grouped under broad subject headings like Awards, Bibliometric studies, Highly cited articles, etc and then a very brief description has been provided.
\end{abstract}

Keywords: Bibliometrics, Eugene Garfield, Essays, Information science

Garfield, now $88+$, is a multifaceted personality. He is an information scientist of world renown, a library scientist by education, a bibliometrician of unparallel magnitude, a multilinguist, a successful entrepreneur, a musician, a consummate lover of art and above all a prolific author. For a long time of his life, he has contributed every week an essay as the editorial of his brainchild Current Contents. This apart he has been a prolific contributor of papers in journals, penned books and letters, compiled directories and so on. One can have an idea about the volume of his writings from the fact that the first five volumes of his essays ${ }^{[1]}$ total around 750. To my knowledge, no other person of library science equals Garfield as far as the quantum of writing is concerned.

Going through the 15 volumes of his essays is but a lifetime experience. There is hardly any area of knowledge be it science and technology, social sciences, or arts and humanities, which his pen has not touched. All

*Address for correspondence:

E-mail: bksen1938@gmail.com

\begin{tabular}{|l|l|}
\hline \multicolumn{2}{|c|}{ Access this article online } \\
\hline Quick Response Code: & \\
\hline & Website: \\
\hline & www.jscires.org \\
& \\
\hline
\end{tabular}

these provide infallible evidence as to the unbelievable expanse of his knowledge that at any rate is no less than encyclopedic. The articles amply help widen the horizon of one's knowledge and witness the universe with a wide perspective.

In these essays, one will find articles even on common subjects such as citation analysis and citation index. On the other hand, uncommon subjects such as absurdity, avian linguistics, chemical linguistics, citation amnesia, thanatology, etc., have not been left out.

Given below is the very brief glimpses of some of the articles arranged under broad subject headings based on analysis of five volumes of essays. ${ }^{[1]}$

\section{AWARDS}

Several articles were devoted to such awards as NAS James Murray Luck Award for Excellence in Scientific Reviewing and ASIS Outstanding Information Science Teacher Award. In each article, a brief description about the award is provided along with the short biographical sketch of the awardee.

\section{BIBLIOMETRIC STUDIES}

A very large number of articles depict the results of bibliometric studies. Of course, there is an article on Bradford law as well. Mention about Garfield law of 
concentration, as well as Garfiled's constant, are also there about which I shall talk later on. On citations alone, there are numerous articles. Citation analysis has also been the subject matter of a number of articles. Citation classics, citation impact, citation indexes have been the highly favorite areas of the author's writing. Citation indexes in sociological and historical research ${ }^{[2]}$ is one of the earliest articles of Garfield on the subject. Apart from the areas mentioned below, he has contributed on cluster mapping as well.

Under the series highly cited articles, most cited articles, highly cited authors, most cited authors a large number of bibliometric studies have been conducted covering articles from various branches of knowledge, and journals from various languages.

\section{Highly Cited Articles}

In his series, more than 40 studies were published covering mathematics, physical sciences, life sciences, specific journals, journal from various countries, etc., Later on the name of the series was changed to "most cited articles."

\section{Highly Cited Authors}

Several articles are there on the topic. Mostly contemporary scientists and social scientists have been listed. Later on the articles on the topic appeared under the heading "most cited authors."

\section{Highly Cited Books}

One study reported 100 books most cited by social scientists.

\section{Journal Citation Studies}

A large number of studies have also appeared under the series "journal citation studies". In this type of studies in many cases citations of two journals have been compared, and the findings reported. Sometimes the studies were devoted to citers and citees, journals of particular subjects and countries, journal -self-citation rates, etc.

\section{Most Cited Articles}

The articles of the series identified the most cited articles in physical sciences, life sciences, preclinical basic research, and clinical research during various periods such as 1960 s. About 27 articles were published till 1983.

\section{Most Cited Authors}

Articles on the most cited authors started appearing from volume 3 of the Essays. Till volume 5 there were 15 articles. The methodologies adopted for selecting the authors have been elaborated, and difficulties faced highlighted. The authors selected included scientists and scholars pertaining to mathematics, physical sciences, chemical sciences, life sciences, social sciences, arts and humanities. In the cases of physical and chemical sciences, as well as life sciences 1,000 contemporary authors have been selected.

\section{INSTITUTE OF SCIENTIFIC INFORMATION}

Institute of Scientific Information (ISI) was the dream child of Garfield. There are quite a number of articles about its functioning, newly constructed building, decoration of the building with paintings, and so on.

\section{INSTITUTE OF SCIENTIFIC INFORMATION PRODUCTS AND SERVICES}

A large number of articles are devoted to the publications and services of ISI. Some of them were describing the current features of the service, some others were the announcements of the forthcoming ISI products or services. The information included among others was the starting year, content, periodicity, the rate of subscription, etc., The products and services covered in the essays among others are: Arts and Humanities Citation Index, Atlas of Science, Automatic Subject Citation Alert, Chemical Substructure Index, CHEMTRAN, CompuMath, Current Contents, Transliterated Dictionary of the Russian Language, International Directory of Research and Development Scientists, Genetics Citation Index, Index to Book Reviews, Index to Scientific and Technical Proceedings, Index to Scientific Reviews, Index to Social Sciences and Humanities Proceedings, Journal Citation Index database, Original Article Tear Sheets service, Press Digest, Science Citation Index (SCI), SCISEARCH. Of these products, Garfield has written maximum on Current Contents and SCI. A brief description of the articles on them is given below along with a description of Journal Citation Reports (JCRs) and Social SCI.

\section{CURRENT CONTENTS}

Of all the publications brought out by ISI, Current Contents had been used by maximum number of researchers. Current Contents came into being in 1958 with 
the title Current Contents of Chemical, Pharmaco-Medical and Life Sciences. With the passage of time its readership grew and more and more sections were added. Ultimately, it was coming out in a number of sections covering journals of science and technology, social sciences, arts and humanities. Garfield's writings made announcements of the new sections, changes in the sections in the form of highly informative articles.

\section{Science Citation Index}

Science Citation Index is possibly the most famous reference tool devised by Garfield. He has many writings on this tool. It has been used for various purposes such as compilation of bibliographies, depiction of citation scenario of scientists, evaluation of scientific activities, unraveling the history of science, locating co-citations, identification of primordial papers and so on. The articles have highlighted its usefulness in the completion of citations, correction of citations, overriding of language and terminological barriers, etc., Apart from this, the articles have dwelt on among others the 5-year cumulation, Permuterm Subject Index, its cost and inevitability, inclusion of nonjournal material, and fourth quarterly SCI. Using co-citations figuring in SCI a method was developed to identify the research fronts in various branches of knowledge. ${ }^{[3]}$

\section{Journal Citation Reports}

Possibly one of the most important bibliometric tools, the JCR, which has been extensively used by information scientists, librarians, bibliometricians, and many others for impact factor of journals, and numerous other bibliometric studies. Obviously, a number of articles are there on this particular tool.

\section{Social Science Citation Index}

The citation index was launched in 1973 basing 1000 social science journals. Relevant items were also included in the index from 2000 SCI journals. Quite a few articles have been penned by its creator depicting various features of the service.

\section{LIBRARIES}

Several articles are there on libraries. One of the articles is on the British Library and another on the Library of Congress. The articles provided a good account of the libraries along with their librarians.

\section{MEDICINE}

Most of the articles on medicine dealt with specific diseases such as acne vulgaris, autism, depression, dyslexia, hair loss, halitosis, Herpes simplex virus infections, lactose intolerance, leprosy, nicotine addiction, senility, trichomoniasis, ulcers, etc., All these articles have provided holistically the state-of-the-art account of the ailments including their etiology, diagnosis, treatment, etc. The rest of the articles dealt with drugs such as aspirin, medical cost, medical research, preventive medicine, electroconvulsive therapy, patient compliance and so on.

\section{NOBEL PRIZE}

In 1960s, when SCI was emerging, Garfield selected 50 scientists out of more than a million based on first author citation and opined some of the scientists figuring in the list might receive Nobel Prize in the future. In the very next year, two scientists from that list received the prize and several afterwards. This method of predicting future Nobel laureates has been criticized world over. Still, whenever he produced such a list, invariably a few from the list received the coveted prize. Several articles are devoted to the topic.

\section{PERSONALITIES}

Garfield has written biographical sketches of a large number of persons including his parents (Edith Wolf - mother, Ernest Garofano - step father), brother Robert L Hayne, et al., friends, well-known personalities and Nobel laureates. Some of the personalities covered are Chauncey D. Leake, Jacob Gershon-Cohen, A. E. Cawkell, Herbert S. White, Morton V. Mallin, Richard M. Harris, Samuel Lazerow, Marvin Shroeder, Joshua Lederberg, Henry E. Bliss, Jacob Bronowski, Robert K. Merton, Sir Peter B. Medawar, Ralph Shaw, Harold Urey, Robert A. Day, R. Buckminster Fuller, Albert C. Barnes, V. V. Nalimov, J. D. Bernal, Hilary Koprowski, Sir Hans Krebs, Benjamin Franklin, Carl Djerassi, William D. McElroy, etc.

\section{RESEARCH AND DEVELOPMENT}

When the US government started reducing budget for basic research, Garfield was very much concerned. He expressed his concern through a number of articles. His articles also focused on noise abetment research, evaluation of research, pure and applied research, scientific research film, economic impact of $\mathrm{R}$ and $\mathrm{D}$, etc. 


\section{SCIENCE}

Garfield has contributed a number of articles on science covering such topics as cultural and economic imperialism of science, science for the sake of science, obliteration phenomenon in science, gatekeepers in science, keeping up with science, identification of paradigms in science, unanswered questions of science, negative science, high impact science, French science, science on television, public confidence in science, social impact of science, etc., His article - "Is French science too provincial?" ${ }^{[4]}$ generated a huge uproar in France.

\section{SCIENCE COMMUNICATION}

Garfield has contributed articles on many reputed journals (both high impact and popular) like Nature, New Scientist, Science, Science 80, Science Digest, Omni, Scientific American, Science News, and Discovery. He has also deliberated on the future of scientific journals. Reprints of many of these articles have been published in these volumes. One can find the reprint article "The significant journals of science" published in Nature, ${ }^{[5]}$ a very important contribution of the author. In fact, it has been widely used as a reference source for the selection of scientific journals for libraries as well as for the placing of papers by scientists. There are also very useful articles such as Excerpta Medica - a comprehensive abstracting service on medicine, and another on Index Medicus.

\section{SCIENTISTS}

Several articles on scientists touch diverse areas such as image of scientists in movies and TVs, problem of young scientists in making contacts in conferences, management training for scientists, etc.

\section{OTHER ARTICLES}

Articles on other areas not mentioned above are also many. The subject headings of the articles are as follows: Abbreviations, advertising, air ions, air-conditioners, alcohol, anonymous publications, article titles, author address, author fee, bibliography, bilingualism, biochemistry, biomedicine, cab driver, chemical information, chemical literature, chemical physics, chemical structure, chemical substructure, chiropractic, citation amnesia, citation network, classification, clinical medicine, complaining, computer, computer music, conferences, contents page, copyright, copywriter, creativity, data, date of publication, dictionaries, directories, discovery, doctor-patient relationship, education, English language, environment, errors, ethics, fasting, fine arts, food additives, food shortages, greetings, historiography, holographic engraving, humor, ice cream, index and indexing, impact factor, information center, information entrepreneur, information explosion, information flow, information industry, information retrieval, information science, information science education, information scientist, information service, information system, information theory, informeter, jet lag, journal collection, journal preference, life sciences, machine translation, meaning, memory, miniprint, money exchange, music score, National Science Foundation, OCR, page charge, Philadelphia, philanthropy, pollution, publication and publishing, radio, refereeing, reprint, restaurant, risk analysis, sales promotion, scientific reviewer, scientometrics, smoking, social psychology, paramedics, speech recognition, student grading, sunbath, surname, taxation, technical writing, timeliness, jazz transcription, uncitedness, voicegram, women scientist, world brain, etc., For the lack of time and space brief descriptions of the articles could not be attempted.

\section{CONCLUSION}

The article has given a brief insight of the work being undertaken by the author on historiographical analysis of Grafields's work. The work is expected to lead to two monographs; detailed glimpses of the writings and the other significant quotations of the prolific author. The intention of the author is to inform the research community, particularly the young scholars in information science/bibliometrics, librarians etc., the high relevance of Garfield's work in their research/practice. It also calls for revisiting these works by contemporary scholars/researchers. The author hopes to provide in future, further glimpses of his work.

\section{REFERENCES}

1. Garfield E. Essays of an Information Scientist. Vol. 1-5. Philadelphia: ISI Press: 1977-1983.

2. Garfield E. Citation indexes in sociological and historical research. Am Doc 1963;14:289-91.

3. Small $\mathrm{H}$. Co-citation in the scientific literature; a new measure of the relationship between two documents. J Am Soc Inf Sci 1973;24:265-9.

4. Garfield E. Is French science too provincial? Recherche 1976;7:757-60.

5. Garfield E. Significant journals of science. Nature 1976;264:609-15.

How to cite this article: Sen BK. Eugene Garfield-Glimpses of his writings. J Sci Res 2014;3:57-60.

Source of Support: Nil, Conflict of Interest: None declared 